\title{
Legionella gresilensis sp. nov. and Legionella beliardensis sp. nov., isolated from water in France
}

1 Centre National de Référence des Legionella UPRES EA1655, Faculté de Médecine RTH Laennec, Rue Guillaume Paradin, 69372 Lyon cedex 08, France

2 Laboratoire des Radioisotopes et de Biochimie moléculaire, Hôpital Edouard Herriot, 69437 Lyon cedex 03, France

3 Unité des Entérobactéries, Institut Pasteur, 75724 Paris cedex 15, France

${ }^{4}$ Respiratory Diseases Branch, Meningitis and Special Pathogens Branch, National Center for Infectious Diseases, Centers for Disease Control and Prevention, Atlanta, GA 30333, USA

\author{
François Lo Presti, ${ }^{1} \ddagger$ Serge Riffard,${ }^{1}$ Hélène Meugnier, ${ }^{1}$ \\ Monique Reyrolle, ${ }^{1}$ Yves Lasne, ${ }^{2} \uparrow$ Patrick A. D. Grimont, ${ }^{3}$ \\ Francine Grimont, ${ }^{3}$ Robert F. Benson, ${ }^{4}$ Don J. Brenner, ${ }^{4}$ \\ Arnold G. Steigerwalt, ${ }^{4}$ Jerome Etienne ${ }^{1}$ and Jean Freney ${ }^{1}$
}

Author for correspondence: François Lo Presti. Tel: +33 01697979 60. Fax: +33 0169797920.
e-mail: Francois.Lo-Presti@sanofi-synthelabo.com

Novel Legionella-like isolates, strains Montbéliard A1 ${ }^{\top}$ and Gréoux 11 D13', isolated from two different French water sources, were studied taxonomically and phylogenetically. Morphological and biochemical characterization revealed that they were Gram-negative, aerobic, non-spore-forming bacilli with a cutglass appearance that grew only on L-cysteine-supplemented buffered charcoal yeast extract agar. Phenotypic characterization using fatty acid and ubiquinone profiles and SDS-PAGE analysis confirmed that they were closely related, but distinct from, other species of the genus Legionella, since serotyping could not relate them to any existing serogroup. Genotypic profiles generated by randomly amplified polymorphic DNA and 16S-23S rDNA spacer region PCR analyses were unique for each of these isolates. DNA-DNA relatedness values of strains Montbéliard $\mathrm{A1}^{\top}$ and Gréoux $11 \mathrm{D}^{\top}{ }^{\top}$ to each other and to other Legionella type strains were less than $25 \%$. Phylogenetic affiliation of these organisms obtained by $16 \mathrm{~S}$ rDNA sequence comparisons confirmed that they were distinct from any other known Legionella species. All the above results confirm that these strains constitute two novel species for which the names

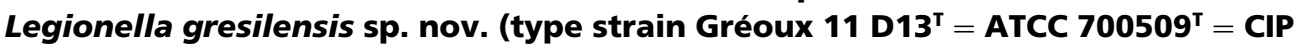
$106631^{\top}$ ) and Legionella beliardensis sp. nov. (type strain Montbéliard A1 ${ }^{\mathrm{T}}=$ ATCC $700512^{\top}=$ CIP 106632 $^{\top}$ ) are proposed.

Keywords: Legionella gresilensis sp. nov., Legionella beliardensis sp. nov., taxonomy, identification

\section{INTRODUCTION}

In 1976, a severe outbreak of pneumonia among veterans of the American Legion, in the city of Philadelphia, led to the discovery of a new genus

† Deceased 11 February 2001.

¥Present address: Sanofi-Synthelabo Recherche, Centre de ChillyMazarin, Génomique Cardiovasculaire/Thrombose, 1 av. Pierre Brossolette, 91385 Chilly-Mazarin cedex, France.

Abbreviations: DFA, direct immunofluorescence assay; LLAPs, Legionellalike amoebal pathogens; RAPD, randomly amplified polymorphic DNA; SAT, slide agglutination test.

The GenBank accession numbers for the 16S rDNA sequences of strains

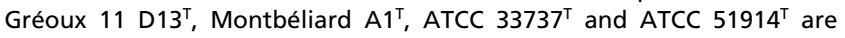
AF122883-AF122886, respectively. subsequently named Legionella. In 1979, this genus was composed of a single species, Legionella pneumophila (Brenner et al., 1979). Since then, the genus has become very large, with 43 species currently recognized (Lo Presti et al., 1999; Franzin \& Gioannini, 2000). These bacteria have been isolated from a large diversity of samples: human clinical specimens, animals (Fabbi et al., 1998), natural and man-made water samples (Fliermans, 1996; Fliermans et al., 1981; Stout et al., 1985), and protozoa (Newsome et al., 1998). However, some species, such as Legionella lytica and other Legionella-like amoebal pathogens (LLAPs), remain unculturable on the buffered charcoal/yeast extract (BCYE) medium normally used to grow legionellae and on all other media tested (Adeleke et al., 1996; Hookey et al., 1996). 
Routine identification of these bacteria is based on phenotypic properties (biochemical tests, serotyping), but molecular biology techniques have resulted in the development of new methods giving a more reliable characterization of Legionella species. Genotyping methods such as ribotyping (Grimont et al., 1989), 16S-23S intergenic spacer region PCR (Riffard et al., 1998), 16S or 5S rRNA gene sequencing (Fry et al., 1991; Adeleke et al., 1996; Birtles et al., 1996; Hookey et al., 1996; Murdoch et al., 1999), macrophage infectivity potentiator (mip) gene sequencing (Ratcliff et al., 1998) and randomly amplified polymorphic DNA (RAPD) (Lo Presti et al., 1998) have been shown to be useful in classifying isolated strains to the species level. These methods are used to supplement DNA relatedness studies, which are used to confirm the designation of strains as novel species. Strains that cannot be recovered onto BCYE can be first characterized by $16 \mathrm{~S}$ rDNA sequencing, which allows them to be classified as legionellae.

Routine investigations of French water from different origins (hospital and thermal spa) frequently lead to the isolation of untypable isolates. After phenotypic characterization, isolates remaining unidentified have been completely typed by genotypic methods. These experiments have allowed identification of two novel species, Legionella beliardensis sp. nov. and Legionella gresilensis sp. nov., isolated from different French water samples.

\section{METHODS}

Isolation procedure. Water samples ( 11 l) were collected from three different locations in France: a thermal spa in the city of Gréoux-les-Bains, a potash mine near Mulhouse and a hospital in Montbéliard. These samples were concentrated by continuous centrifugation and/or filtration to a $10 \mathrm{ml}$ final volume and either left untreated or treated by acidification according to previously described procedures (Bornstein et al., 1989). The resulting samples were cultured on: BCYE agar plates supplemented with $0.1 \%$ 2-oxoglutarate $(\mathrm{BCYE} \alpha) ; \mathrm{BCYE} \alpha$ supplemented with glycine $\left(3 \mathrm{~g} \mathrm{l}^{-1}\right)$, vancomycin $\left(5 \mathrm{mg}^{-1}\right)$ and colistin $\left(5 \mathrm{mg} \mathrm{l}^{-1}\right)$ (GVC medium); and BAB agar which is a BCYE medium supplemented with colistin $\left(16 \mathrm{mg} \mathrm{l}^{-1}\right)$, vancomycin $\left(0.5 \mathrm{mg} \mathrm{l}^{-1}\right)$ and cefalothin $\left(4.23 \mathrm{mg} \mathrm{l}^{-1}\right)$. Controls were done on blood agar and on BCYE $\alpha$ without both L-cysteine and iron. The plates were incubated at $37{ }^{\circ} \mathrm{C}$ in an $80 \% \mathrm{H}_{2} \mathrm{O}$ atmosphere, with or without $2 \cdot 5 \% \mathrm{CO}_{2}$.

Bacterial strains. The eight atypical Legionella isolates (Table 1) were compared with the species and serogroup type strains of 42 Legionella species and 65 serogroups (Table 3). Included in this study were some potentially novel species. The as yet not formally described 'Legionella donaldsonii' (strain 'Glasgow' 86/35784; a gift from T. G. Harrison, Colindale, UK) and strain IB V no. 2 were also compared with our strains. As amoebal cultures were not available, one validly published species, Legionella lytica, could not be used for the DNA hybridization studies (Hookey et al., 1996).

Cultural and biochemical tests. Each strain tested was cultured onto BCYE $\alpha$ or GVC medium when required. Requirement for cysteine on subculture was tested by its omission when preparing the BCYE $\alpha$ media. Autofluorescence of the strains was tested by examining cultures under Wood's light (366 nm). Tests for catalase, oxidase, $\beta$ lactamase, hippurate hydrolysis, urease, glucose utilization, gelatinase, nitrate reduction and presence of flagella were done as previously described (Brenner et al., 1985). Browning of tyrosine-supplemented agar was considered positive if the browning produced around the colonies was larger on tyrosine-supplemented agar than any browning produced around the colonies of the same strain on tyrosine-free agar after 3 d growth (Vickers \& Yu, 1984). The colour of the colonies was also noted on plates containing DGVP agar, a GVP medium modified by the addition of dyes (bromocresol purple and bromothymol blue) allowing a visual differentiation between Legionella (Tatlockia) micdadei, Legionella (Tatlockia) maceachernii (colonies are blue) and the other species of Legionella (colonies are green) (Vickers et al., 1987).

Direct immunofluorescence assays. The eight Legionella isolates were identified by performing direct immunofluorescence assays (DFA) using 60 hyperimmune rabbit antisera prepared as described previously (Cherry et al., 1978). Antisera were not available for four species: Legionella genomospecies 1, Legionella lansingensis, Legionella shakespearei and Legionella waltersii. Conversely, all of the 65 serogroup reference strains were tested by DFA using antisera prepared against strain Gréoux $11 \mathrm{D} 13^{\mathrm{T}}$ and against strain Montbéliard $\mathrm{A} 1^{\mathrm{T}}$.

Slide agglutination test. Both type strains were tested at the Centers for Disease Control (Atlanta, GA, USA) with

Table 1. Biochemical characteristics of the isolates

w, Weak; +w, weakly positive; v, variable.

\begin{tabular}{|c|c|c|c|c|c|c|}
\hline Strain & Oxidase & $\beta$-Lactamase & Hippurate hydrolysis & Tyrosinase & Gelatinase & Voges-Proskauer \\
\hline Gréoux $11 \mathrm{D} 13^{\mathrm{T}}$ & $+\mathrm{w}$ & $+\mathrm{w}$ & + & $\mathrm{V}$ & $+($ slow $)$ & - \\
\hline Mulhouse 12 A22 & $+\mathrm{w}$ & + & $+\mathrm{w}$ & - & + & - \\
\hline Mulhouse 12 A23 & $+\mathrm{w}$ & + & $+\mathrm{w}$ & - & + & - \\
\hline Montbéliard $\mathrm{A} 1^{\mathrm{T}}$ & $\mathrm{V}$ & + & - & - & + & + \\
\hline Montbéliard A2 & - & + & - & - & + & + \\
\hline Montbéliard A3 & - & + & - & - & + & - \\
\hline Montbéliard A4 & + & + & - & - & + & - \\
\hline Montbéliard A5 & + & + & - & - & + & - \\
\hline
\end{tabular}


the slide agglutination test (SAT) using antisera representing all species and serogroups of Legionella. Antisera prepared against the type strains of both novel species were tested against antigens for all species and serogroups of Legionella. Antisera and antigens for the SAT were prepared, tested and absorbed as described previously (Thacker et al., 1985).

Cell wall fatty acids and isoprenoid quinone composition. Cell wall fatty acids and isoprenoid quinones were assayed as described previously (Lambert \& Moss, 1989) for strains Montbéliard $\mathrm{A} 1^{\mathrm{T}}$, Montbéliard A2, Montbéliard A3, Montbéliard A4 (ubiquinones only), Gréoux 11 D13 ${ }^{\mathrm{T}}$ and Mulhouse 12 A22 (fatty acids only) grown on BCYE agar plates for $48-96 \mathrm{~h}$ at $37^{\circ} \mathrm{C}$.

Protein profile analysis. The protein electrophoretic patterns of the five isolates from Montbéliard and strain Gréoux 11 D $13^{\mathrm{T}}$ were compared with each other and with other species after SDS-PAGE according to a previously described technique (Bornstein et al., 1989).

Genotypic characterization. DNA was extracted by the boiling water method (Gomez-Lus et al., 1993) and purified with phenol/chloroform/isoamyl alcohol (25:24:1), followed by ethanol precipitation. RAPD analysis was performed with primer SK2 (5'-CGGCGGCGGCGG-3') (Meunier \& Grimont, 1993) as described previously (Lo Presti et al., 1997). Amplification of the intergenic 16S-23S ribosomal spacer by PCR was done using primers FGPS1490-72 (5'-TGCGGCTGGATCCCCTCCTT-3') and FGPL132'-38 (5'-CCGGGTTTCCCCATTCGG-3') as published recently (Riffard et al., 1998). Each RAPD and 16S-23S genotypic profile (both faint and intensive bands were used) was analysed by the TAXOTRON package (Taxolab, Institut Pasteur, Paris, France) using the Dice coefficient (Dice, 1945) and clustering was based on the single linkage method. Profiles for all Legionella species and serogroups described and for some additional potentially novel species were available for comparisons.

16S rDNA amplification and sequencing. DNA amplification of the $16 \mathrm{~S}$ rRNA gene was performed by using oligonucleotide primers L16A1 (5'-AGA GTT GGA TCC TGG CTC AG-3') and L16r1488 (5'-GAC TTC ACC CCA GTC ATG AA-3'), corresponding to positions 8-27 and 1488-1508, respectively, in Escherichia coli numbering (Brosius et al., 1978). Sequencing was done by the dideoxy chain termination method (Sanger et al., 1977) under conditions described previously (Lo Presti et al., 1997) and the sequences of strains Gréoux $11 \mathrm{D}^{\mathrm{T}} 3^{\mathrm{T}}$ and Montbéliard $\mathrm{Al}^{\mathrm{T}}$ were compared using the gapped BLAST program (Altschul et al., 1997) with previously published sequences (Adeleke et al., 1996; Birtles et al., 1996; Fry et al., 1991; Hookey et al., 1996) and those available in the DDBJ, EMBL and GenBank databases through the Internet (http://www.ncbi.nlm.nih.gov). For this study, sequencing of the recently described L. waltersii ATCC $51914^{\mathrm{T}}$ (Benson et al., 1996) and Legionella pneumophila subsp. pascullei ATCC $33737^{\mathrm{T}}$ (Brenner et al., 1988) was performed.

Phylogenetic analyses. Phylogenetic analyses were performed with the Wisconsin package version 10.0 of the Genetics Computer Group (GCG, Madison, WI, USA). The 16S rDNA gene sequences were first aligned using the PILEUP program and the resulting multi-sequence alignment was subsequently manually corrected. A total of $1304 \mathrm{nt}$ ranging from positions 34 to 1338 , according to $E$. coli numbering (Brosius et al., 1978), was included in this study. Kimura's two-parameter distance matrices and the resulting unrooted tree were done using DISTANCE and GROWTREE programs.
DNA studies. DNA was extracted and purified as previously described (Brenner et al., 1982) and the native DNA was labelled by nick-translation with ${ }^{3} \mathrm{H}$-labelled nucleotides (Pharmacia Biotech). DNA-DNA hybridization with all species (Table 3) was performed using the standard S1nuclease method (Grimont et al., 1980). The thermal stability of heterologous hybrids was calculated by a standard method (Crosa et al., 1973).

The DNA $\mathrm{G}+\mathrm{C}$ content of our strains was determined by HPLC of nucleotides after hydrolysis of the DNA by P1 nuclease (Kaneko et al., 1986) and also spectrophotometrically by the thermal denaturation method (Marmur \& Doty, 1962).

\section{RESULTS}

\section{Isolation, growth and biochemical characterization}

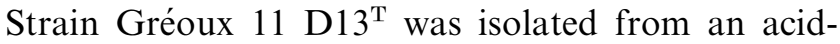
treated water sample from a shower in a thermal spa in the city of Gréoux, France after $3 \mathrm{~d}$ growth on BAB media. The same water sample also yielded L. pneumophila (undetermined serogroup 8 or 10), Legionella anisa, Legionella rubrilucens and Legionella londiniensis. Strains Mulhouse 12 A22 and Mulhouse 12 A23 were isolated from a water sample obtained from a potash mine located near Mulhouse in France. Strains Montbéliard $\mathrm{A}^{\mathrm{T}}$ to Montbéliard A5 were isolated from GVC media after $10 \mathrm{~d}$ growth from an acidtreated water sample from a calorifier in a reanimation unit of a hospital in Montbéliard, France.

All of these isolates grew on BCYE $\alpha$ and GVC media; however, the strains from Montbéliard grew very slowly. None of the isolates grew on blood agar or on $\mathrm{BCYE} \alpha$ lacking supplemented L-cysteine. They were non-spore-forming, Gram-negative rods with a single polar flagellum. Biochemical tests were positive for the presence of catalase. These isolates gave negative reactions for urease, carbohydrate fermentation and nitrate reduction. Other biochemical characteristics are shown in Table 1. Autofluorescence under UV light was absent for all isolates; however, a yellowgreen fluorescence of the growth medium was produced around the colonies. Colonies were greenish on DGVP medium.

\section{Table 2. Ubiquinone contents of the isolates}

For the quinones, the figure indicates the number of isoprene units, e.g. Q-9 indicates that the quinone contains 9 isoprene units. Relative amounts of ubiquinones are shown, with the major component designated by a score of 4 . - , None detected; TR, trace amount.

\begin{tabular}{|lcccccc|}
\hline Strain & Q-9 & Q-10 & Q-11 & Q-12 & Q-13 & Q-14 \\
\hline Gréoux 11 D13 $^{\mathrm{T}}$ & - & - & $1 \cdot 3$ & 4 & $0 \cdot 4$ & - \\
Montbéliard A1 $^{\mathrm{T}}$ & $0 \cdot 2$ & $0 \cdot 1$ & $0 \cdot 5$ & 4 & $1 \cdot 5$ & - \\
Montbéliard A2 & $0 \cdot 2$ & $0 \cdot 1$ & $0 \cdot 5$ & 4 & $1 \cdot 5$ & $\mathrm{TR}$ \\
Montbéliard A3 $^{0}$ & $0 \cdot 2$ & $0 \cdot 2$ & $0 \cdot 6$ & 4 & $1 \cdot 4$ & - \\
Montbéliard A4 & $0 \cdot 2$ & $0 \cdot 5$ & $0 \cdot 9$ & 4 & $1 \cdot 6$ & - \\
\hline
\end{tabular}




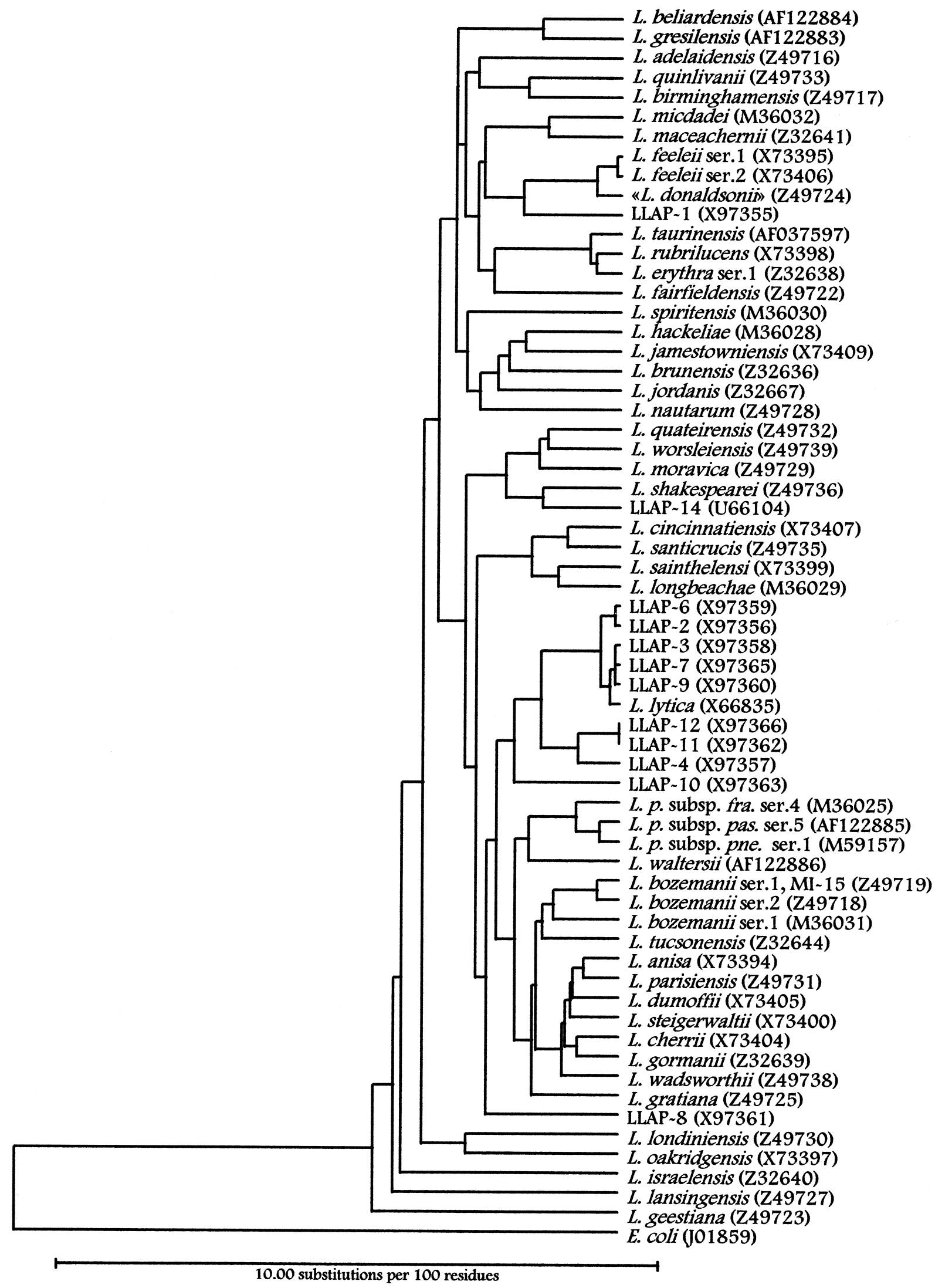

Fig. 1. Unrooted $16 \mathrm{~S}$ rDNA phylogenetic tree. The GenBank/EMBL accession numbers are given in parentheses. $L$. $p$. subsp. pne., Legionella pneumophila subsp. pneumophila; L. p. subsp. pas., Legionella pneumophila subsp. pascullei; L. p. subsp. fra., Legionella pneumophila subsp. fraseri; ser., serogroup. 


\section{DFA and SAT}

The five strains from Montbéliard gave negative reactions with all 65 heterogeneous antisera tested. The same five isolates reacted with a level of $4+$ when tested with an antiserum prepared against strain Montbéliard $\mathrm{A} 1^{\mathrm{T}}$. This antiserum was negative when tested against all Legionella species and serogroups. In the SAT test, the type strain was negative with specific antisera of each Legionella species and serogroups. Antiserum prepared against the type strain gave reactions of $4+$ with the homologous strain and was negative when tested against all Legionella species and serogroup type strains. Strain Gréoux $11 \mathrm{D}^{\mathrm{T}} 3^{\mathrm{T}}$ first reacted with a level of + to $2+$ against $L$. anisa unabsorbed antiserum; however, this reaction was not reproducible. Antiserum developed against the Gréoux $11 \mathrm{D} 13^{\mathrm{T}}$ isolate gave a fluorescence of $4+$ with the homologous strain and with the two isolates from Mulhouse. No reactions were noted against any Legionella species or serogroups. In the SAT test, strain Gréoux $11 \mathrm{D} 13^{\mathrm{T}}$ was negative with antisera for all Legionella species and serogroups. Antiserum prepared against Gréoux $11 \mathrm{D} 13^{\mathrm{T}}$ was negative against all Legionella species and serogroups.

\section{Cellular fatty acids and ubiquinone composition}

Non-hydroxy fatty acids comprised more than $90 \%$ of the total fatty acid composition for each strain tested. Three strains from Montbéliard contained cis-9-hexadecanoate $(16: 1)$ as their major fatty acid $(31 \%)$, followed by hexadecanoate $(16: 0)$ which accounted for $20 \%, 18: 1(15 \%)$, octadecanoate $(18: 0)$ for $11 \%$ and 14-methylhexadecanoate (a17:0) for 9\%. Other fatty acids were present, but each in quantities less than $8 \%$. Strains Gréoux $11 \mathrm{D} 13^{\mathrm{T}}$ and Mulhouse 12 A22 were also characterized by a large quantity of cis9-hexadecanoate, accounting for $33 \%$ of the total fatty acids. These strains also contained appreciable amounts of 14-methylpentadecanoic acid (i16:0) $(13 \%)$, followed by 16:0 and a17:0 (9\%) and minor fatty acids, each accounting for $8 \%$. Isolates from Montbéliard and strain Gréoux $11 \mathrm{D}^{\mathrm{T}} 3^{\mathrm{T}}$ had ubiquinone profiles dominated by the presence of quinone Q-12 (Table 2).

\section{SDS-PAGE analysis}

Protein profiles obtained from strains Montbéliard $\mathrm{A} 1^{\mathrm{T}}$, Montbéliard A2 and Montbéliard A3 were 95-100\% homologous. Protein profiles of Montbéliard A4 and Montbéliard A5 were $100 \%$ homologous, but only $74-79 \%$ homologous to other Montbéliard strains. However, homology of the 'Montbéliard' cluster was less than $70 \%$ with all known Legionella species. The protein profiles of strain Gréoux $11 \mathrm{D} 13^{\mathrm{T}}$ were also different from those of all known Legionella species (less than $60 \%$ homology).

\section{RAPD analysis}

The RAPD profiles obtained for strains belonging to the 'Montbéliard' cluster were identical. The two strains from Mulhouse gave a profile identical to that of Gréoux $11 \mathrm{D} 13^{\mathrm{T}}$. The RAPD patterns of these 'Gréoux' and 'Montbéliard' clusters were different from those obtained for all the other Legionella species tested. These species were named Legionella sp. 1 and sp. 3, respectively, in a previous publication (Lo Presti et al., 1998).

\section{S-23S intergenic spacer region PCR analysis}

The patterns obtained for strains belonging to the 'Gréoux' and 'Montbéliard' clusters were unique and could be easily differentiated from any other profile generated by the known Legionella species. These two clusters were previously named Legionella sp. Type 1 and Type 13, respectively (Riffard et al., 1998).

\section{S rRNA gene analysis and phylogenetic studies}

The comparison of $1430 \mathrm{bp}$ (gaps excluded from the analysis) of the aligned 16S rRNA gene sequences of the strains Gréoux $11 \mathrm{D}^{\mathrm{T}} 3^{\mathrm{T}}$ and Montbéliard $\mathrm{A} 1^{\mathrm{T}}$ showed they were $97.83 \%$ identical (31 different nucleotides). The nearest species was $L$. micdadei (GenBank no. AF227162) with identities of $96.88 \%$ (1408 nt compared with the sequence for strain Gréoux $11 \mathrm{D} 13^{\mathrm{T}}$ ) and $95.62 \%$ (1437 $\mathrm{nt}$ compared with the sequence for strain Montbéliard $\mathrm{Al}^{\mathrm{T}}$ ). The two sequences were less related to each of the $16 \mathrm{~S}$ rDNA sequences of the described Legionella species (LLAP strains included). Phylogenetic relationships obtained from these data are shown in Fig. 1.

\section{DNA hybridization}

As shown in Table 3, DNA-DNA hybridization studies of strain Gréoux $11 \mathrm{D} 13^{\mathrm{T}}$ revealed a high level of reassociation with DNA from isolates Mulhouse 12 A22 and Mulhouse 12 A23, with more than 90\% relatedness in both optimal and stringent reactions. The nearest species was represented by those of the 'Montbéliard' cluster with only $24 \%$ relatedness. The four strains from Montbéliard were also more than $95 \%$ inter-related. Again, the nearest species was $L$. micdadei with 22 and $15 \%$ relatedness with strains

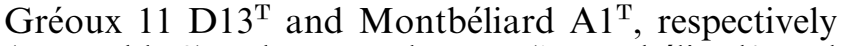
(see Table 3). The two clusters ('Montbéliard' and 'Gréoux') exhibited $12 \%$ or less relatedness to all other Legionella species.

\section{DNA base composition}

The $\mathrm{G}+\mathrm{C}$ content of strain Gréoux $11 \mathrm{D}^{\mathrm{T}} \mathrm{3}^{\mathrm{T}}$ was $33 \mathrm{~mol} \%$ by each of the two methods used. Montbéliard $\mathrm{A}^{\mathrm{T}}$ strain had $\mathrm{a} \mathrm{G}+\mathrm{C}$ content of 
Table 3. DNA relatedness of strains Gréoux $11 \mathrm{D} 13^{\top}$ and Montbéliard $\mathrm{A}^{\top}{ }^{\top}$ with Legionella spp.

\begin{tabular}{|c|c|c|c|c|c|c|}
\hline \multirow[t]{3}{*}{ Source of unlabelled DNA } & \multicolumn{6}{|c|}{ Relatedness (\%) to labelled DNA from: } \\
\hline & \multicolumn{3}{|c|}{ Gréoux 11 D13 } & \multicolumn{3}{|c|}{ Montbéliard A1 ${ }^{\mathrm{T}}$} \\
\hline & $60^{\circ} \mathrm{C}^{*}$ & $70^{\circ} \mathrm{C}^{*}$ & $60{ }^{\circ} \mathrm{C} \dagger$ & $60{ }^{\circ} \mathrm{C}^{*}$ & $70^{\circ} \mathrm{C}^{*}$ & $60{ }^{\circ} \mathrm{C}$ \\
\hline Gréoux $11 \mathrm{D} 13^{\mathrm{T}}\left(=\right.$ ATCC $\left.700509^{\mathrm{T}}\right) \dagger$ & 100 & 100 & 100 & 24 & ND & ND \\
\hline Mulhouse 12 A22 (= ATCC 700758) & 100 & 93 & ND & ND & ND & ND \\
\hline Mulhouse 12 A23 (= ATCC 700759) $\$$ & 100 & 92 & ND & ND & ND & ND \\
\hline Montbéliard $\mathrm{A} 1^{\mathrm{T}}\left(=\right.$ ATCC $\left.700512^{\mathrm{T}}\right) \S$ & 24 & ND & 26 & 100 & 100 & 100 \\
\hline Montbéliard A2 $(=$ ATCC 700760)§ & ND & ND & ND & 100 & 100 & ND \\
\hline Montbéliard A3§ & ND & ND & ND & 100 & 100 & ND \\
\hline Montbéliard A4§ & ND & ND & ND & 95 & 90 & ND \\
\hline Legionella adelaidensis ATCC $49625^{\mathrm{T}}$ & 5 & ND & ND & 2 & ND & ND \\
\hline Legionella anisa ATCC $35292^{\mathrm{T}}$ & 5 & ND & ND & 7 & ND & ND \\
\hline Legionella birminghamensis ATCC $43702^{\mathrm{T}}$ & 3 & ND & 5 & 10 & ND & 7 \\
\hline Legionella (Fluoribacter) bozemanii sg.1 ATCC $33217^{\mathrm{T}}$ & 5 & ND & 8 & 9 & ND & 8 \\
\hline Legionella brunensis ATCC $43878^{\mathrm{T}}$ & 8 & ND & 6 & 9 & ND & 9 \\
\hline Legionella cherrii ATCC $35252^{\mathrm{T}}$ & 4 & ND & ND & 9 & ND & ND \\
\hline Legionella cincinnatiensis ATCC $43753^{\mathrm{T}}$ & 6 & ND & 5 & 6 & ND & 7 \\
\hline 'Legionella donaldsonii' strain LC 878 & 2 & ND & ND & 11 & ND & ND \\
\hline Legionella (Fluoribacter) dumoffii ATCC $33279^{\mathrm{T}}$ & 4 & ND & 4 & 8 & ND & 7 \\
\hline Legionella erythra serogroup 1 ATCC $35303^{\mathrm{T}}$ & 8 & ND & 5 & 2 & ND & 9 \\
\hline Legionella fairfieldensis ATCC $49588^{\mathrm{T}}$ & 1 & ND & 6 & 5 & ND & 8 \\
\hline Legionella feeleii serogroup 1 ATCC $35072^{\mathrm{T}}$ & 1 & ND & 5 & 6 & ND & 9 \\
\hline Legionella geestiana ATCC $49504^{\mathrm{T}}$ & 2 & ND & 4 & 3 & ND & 5 \\
\hline Legionella genomospecies 1 (= ATCC 51913) & 8 & ND & 5 & 9 & ND & 5 \\
\hline Legionella (Fluoribacter) gormanii ATCC $33297^{\mathrm{T}}$ & 5 & ND & 5 & 5 & ND & 6 \\
\hline Legionella gratiana ATCC $49413^{\mathrm{T}}$ & 2 & ND & 7 & 5 & ND & 7 \\
\hline Legionella hackeliae serogroup 1 ATCC $35250^{\mathrm{T}}$ & 7 & ND & 6 & 7 & ND & 9 \\
\hline Legionella israelensis ATCC $43119^{\mathrm{T}}$ & 5 & ND & 2 & 7 & ND & 4 \\
\hline Legionella jamestowniensis ATCC $35298^{\mathrm{T}}$ & 7 & ND & 6 & 7 & ND & 8 \\
\hline Legionella jordanis ATCC $33623^{\mathrm{T}}$ & 6 & ND & 4 & 4 & ND & 7 \\
\hline Legionella lansingensis ATCC $49751^{\mathrm{T}}$ & 10 & ND & 8 & 5 & ND & 10 \\
\hline Legionella londiniensis ATCC $49505^{\mathrm{T}}$ & 0 & ND & 7 & 6 & ND & 6 \\
\hline Legionella longbeachae serogroup 1 ATCC $33462^{\mathrm{T}}$ & 8 & ND & 4 & 8 & ND & 7 \\
\hline Legionella lytica & ND & ND & ND & ND & ND & ND \\
\hline Legionella (Tatlockia) maceachernii ATCC $35300^{\mathrm{T}}$ & 3 & ND & 3 & 6 & ND & 9 \\
\hline Legionella (Tatlockia) micdadei ATCC $33218^{\mathrm{T}}$ & 22 & ND & 20 & 6 & ND & 15 \\
\hline Legionella moravica ATCC $43877^{\mathrm{T}}$ & 5 & ND & 5 & 6 & ND & 7 \\
\hline Legionella nautarum ATCC $49506^{\mathrm{T}}$ & 5 & ND & 6 & 7 & ND & 9 \\
\hline Legionella oakridgensis ATCC $33761^{\mathrm{T}}$ & 3 & ND & 4 & 4 & ND & ND \\
\hline Legionella parisiensis ATCC $35299^{\mathrm{T}}$ & 5 & ND & 4 & 5 & ND & 6 \\
\hline Legionella pneumophila subsp. pneumophila ATCC $33152^{\mathrm{T}}$ & 3 & ND & 4 & 3 & ND & 6 \\
\hline Legionella quateirensis ATCC $49507^{\mathrm{T}}$ & 4 & ND & 6 & 6 & ND & 6 \\
\hline Legionella quinlivanii serogroup 1 ATCC $43830^{\mathrm{T}}$ & 8 & ND & 6 & 8 & ND & 8 \\
\hline Legionella rubrilucens ATCC $35304^{\mathrm{T}}$ & 4 & ND & ND & ND & ND & ND \\
\hline Legionella sainthelensi serogroup 1 ATCC $35248^{\mathrm{T}}$ & 12 & ND & 3 & 7 & ND & 7 \\
\hline Legionella santicrucis ATCC $35301^{\mathrm{T}}$ & 3 & ND & ND & ND & ND & $\mathrm{ND}$ \\
\hline Legionella shakespearei ATCC $49655^{\mathrm{T}}$ & 2 & ND & 5 & ND & ND & 6 \\
\hline Legionella spiritensis serogroup 1 ATCC $35249^{\mathrm{T}}$ & 1 & ND & 2 & ND & ND & 6 \\
\hline Legionella steigerwaltii ATCC $35302^{\mathrm{T}}$ & 0 & ND & ND & ND & ND & ND \\
\hline Legionella taurinensis ATCC $700508^{\mathrm{T}}$ & 0 & ND & ND & 0 & ND & ND \\
\hline Legionella tucsonensis ATCC $49180^{\mathrm{T}}$ & 2 & ND & 6 & ND & ND & 8 \\
\hline Legionella wadsworthii ATCC $33877^{\mathrm{T}}$ & 1 & ND & 1 & ND & ND & 6 \\
\hline Legionella waltersii ATCC $51914^{\mathrm{T}}$ & 0 & ND & 5 & ND & ND & 5 \\
\hline Legionella worsleiensis ATCC $49508^{\mathrm{T}}$ & 5 & ND & 5 & ND & ND & 6 \\
\hline Strain IB V no. 2 (= ATCC 700511$)$ & 1 & ND & 5 & ND & ND & 6 \\
\hline
\end{tabular}

ND, Not done.

* Reactions were done at least in duplicate at $60{ }^{\circ} \mathrm{C}$. Relatedness by S1-nuclease method. Standard deviation was less than $2 \%$. The maximum deviation between two determinations was $5 \%$.

$\dagger$ Relatedness by hydroxyapatite method. Reactions were done in duplicate with mean and maximum deviations of $1 \cdot 4$ and $4 \cdot 0 \%$, respectively.

t Strains of the cluster 'Gréoux'.

$\S$ Strains of the cluster 'Montbéliard'. 
$38 \mathrm{~mol} \%$, whereas strain Montbéliard A4 had a G + C content of $37 \mathrm{~mol} \%$.

\section{DISCUSSION}

The health risks associated with the presence of Legionella isolates in potable and non-potable water available to the public frequently results in a survey of these water systems for Legionella. During such investigations, several atypical isolates were recovered. On the basis of cultural criteria, these strains appeared to belong to the genus Legionella, but remained untypable by routine techniques.

Among these techniques, biochemical characteristics were typical of the majority of legionellae in that these strains were catalase-positive, but were unable to reduce nitrate to nitrite. They were also negative for carbohydrate fermentation and presence of urease. Two strains from Montbéliard had an unusual biochemical reaction in that they were positive for the Voges-Proskauer test, which is indicative of a possible butylene glycol type of fermentation in these strains.

Except for a weak positive reaction of strain Gréoux 11 $\mathrm{D} 13^{\mathrm{T}}$ with an unabsorbed antiserum prepared against L. anisa, none of the isolates reacted with any Legionella species or serogroup-specific antisera. Antisera made against these atypical strains revealed specific serotyping reactions. This absence of identification to the species or serogroup level on the basis of serotyping led us to pursue the identification of these putative Legionella isolates by determining their fatty acid composition. The results completely fit the criteria of the genus Legionella since their cellular composition is predominantly branch-chained fatty acids (Wilkinson et al., 1990). With their fatty acid composition, both clusters were placed in the C16 group (Lambert \& Moss, 1989). The isoprenoid quinone composition of the 'Gréoux' and 'Montbéliard' clusters was also typical of Legionella species, with long side chains containing 10 or more isoprene units. This composition placed these two clusters in ubiquinone group A of Lambert \& Moss (1989). All these methods (cultural and biochemical characteristics, fatty acid and ubiquinone composition) are useful for ascribing strains to Legionella at the genus level, but cannot be used to determine whether they represent novel species or serotypes of existing species.

Previous genotyping analysis by RAPD (Lo Presti et al., 1998) and 16S-23S intergenic spacer region PCR (Riffard et al., 1998) did not resolve their identification in that no good correlations with existing species were found. The two clusters were represented by a unique profile revealing that they were potentially novel species. Moreover, these results correlated well with those obtained by SDS-PAGE analysis and serotyping. Except for the problem of serotypic cross-reaction, these four methods confirmed their usefulness in speciating strains.
When comparing the 16S rDNA sequences of strains Gréoux $11 \mathrm{D} 13^{\mathrm{T}}$ and Montbéliard $\mathrm{A} 1^{\mathrm{T}}$ with each Legionella and LLAP 16S rDNA sequence, the highest homology $(97.83 \%)$ was found between the two new clusters, whereas the other species (including LLAP strains) were less than $97 \%$ related. The phylogenetic study supported this relationship by clustering them in the same branch of the tree (Fig. 1). It is generally accepted that strains with $16 \mathrm{~S}$ rRNA gene homology under $97 \%$ are members of different species (Stackebrandt \& Goebel, 1994). The level of homology for clusters 'Gréoux' and 'Montbéliard' was less than that necessary to confirm their status as one or two potentially novel species. In previous publications, it has been shown that, in the legionellae, two different species can reach as high as $99.4 \% 16 \mathrm{~S}$ rRNA gene homology (Hookey et al., 1996; Lo Presti et al., 1999). The high level of similarity between the small subunit rDNA gene of the two clusters clearly indicated that DNA pairing studies needed to be performed firstly between them, secondly with $L$. micdadei and then with other Legionella species. If these DNA pairing studies revealed them as novel genomic species, it is the presence or absence of specific phenotype that should be the deciding factor about whether to name them.

DNA hybridization studies yielded results similar to those from $16 \mathrm{~S}$ rDNA comparisons, showing that these two clusters were related but distinct from any other Legionella species. These experiments revealed that the two groups completely fitted the genetic definition of a species (Wayne et al., 1987). The two clusters were each homogeneous, with more than $90 \%$ DNA relatedness between the strains tested (Table 3). These two groups showed relatedness for each other, but the DNA-DNA relatedness was only $24 \%$ at optimal reassociation criteria. It is interesting to note that one of their nearest 16S rDNA phylogenetic branches, containing L. micdadei and L. maceachernii, was confirmed by DNA-DNA hybridization results (15-22\% relatedness), indicating that they are their closest relatives. However, these latter species are easily differentiated from our atypical strains by serotyping and colour of the colonies on DGVP media. The dark blue colour that can be obtained for colonies grown on this media is still restricted to the species $L$. micdadei and L. maceachernii (Vickers et al., 1987).

A large number of Legionella species has been described on the basis of a single strain description (Brenner et al., 1985; Bornstein et al., 1989; Benson et al., 1996). As legionellae are of medical importance, the description of a novel species, although a unique strain, can help in the identification of legionellosis due to an atypical isolate as shown recently for Legionella parisiensis (Lo Presti et al., 1997). In our case, the cluster 'Gréoux' has been characterized with strains isolated from two different locations. Each isolate of this cluster has strictly identical phenotypic characteristics and has been shown by genotypic, $16 \mathrm{~S}$ rDNA and DNA studies to belong to a unique species. In the case of the cluster 'Montbéliard', the five isolates were 
recovered from only one location. The slight phenotypic differences in biochemical characteristics and protein profiles noted for isolates Montbéliard A4 and A5 compared to the type strain revealed that the five selected isolates belonged to at least two different strains. However, DNA studies clearly demonstrated that they belonged to the same species with more than $95 \%$ DNA homology. These two novel species can be phenotypically identified by serotyping, a criterion usually required for describing novel Legionella species (Benson et al., 1996; Ursing et al., 1995). The sum total of our results confirms the 'Montbéliard' and 'Gréoux' clusters as novel Legionella species (Legionella beliardensis sp. nov. and Legionella gresilensis $\mathrm{sp}$. nov., respectively).

While this manuscript was being edited, three LLAP strains cited in this study were described as three novel species by Adeleke et al. (2001): Legionella drozanskii sp. nov., type strain LLAP- $1^{\mathrm{T}}$; Legionella rowbothamii sp. nov., type strain LLAP- ${ }^{\mathrm{T}}$; and Legionella fallonii sp. nov., type strain LLAP- $10^{\mathrm{T}}$. The numbering of our novel species is made according to Adeleke et al. (2001).

\section{Description of Legionella beliardensis sp. nov.}

Legionella beliardensis (be.li.ar.den'sis. M.L. adj. beliardensis pertaining to Montbéliard, France, whose classical Latin name was Montem Beliardae).

Gram-negative rod with a single polar flagellum. Positive for catalase, gelatinase and presence of $\beta$ lactamase. Negative for urease, nitrate reduction, acid production from D-glucose, browning of tyrosine agar and hippurate hydrolysis. Some strains are positive for the Voges-Proskauer test. DFA and SAT results exhibit no serological cross-reaction with any other Legionella species. Major ubiquinone is Q-12. All strains were isolated from water samples from a single French city, Montbéliard. The type strain is Montbéliard A1 ${ }^{\mathrm{T}}\left(=\right.$ ATCC $700512^{\mathrm{T}}=$ CIP $\left.106632^{\mathrm{T}}\right)$, isolated from a calorifier in a hospital in Montbéliard (France). It has a $\mathrm{G}+\mathrm{C}$ content of $38 \mathrm{~mol} \%$. Strains Montbéliard A2 (= ATCC 700760), Montbéliard A3, Montbéliard A4 and Montbéliard A5 are additional strains of this species.

\section{Description of Legionella gresilensis sp. nov.}

Legionella gresilensis (gre.si.len'sis. M.L. adj. gresilensis pertaining to Gréoux, a French spa city, whose classical Latin name was Gresilium).

Gram-negative rod with a single polar flagellum. Positive for catalase, oxidase, gelatinase, hippurate hydrolysis and presence of $\beta$-lactamase. Negative for urease, nitrate reduction, acid production from Dglucose and browning of tyrosine agar. DFA and SAT results indicate no serological cross-reactions with any Legionella species. Major ubiquinone is Q-12. All strains were isolated from water samples in France. The type strain is Gréoux $11 \mathrm{D} 13^{\mathrm{T}}$ (= ATCC $700509^{\mathrm{T}}$ $=$ CIP $106631^{\mathrm{T}}$ ), isolated from a thermal spa water in the city of Gréoux (France). It has a $\mathrm{G}+\mathrm{C}$ content of $33 \mathrm{~mol} \%$. Strains Mulhouse 12 A22 (= ATCC 700758) and Mulhouse 12 A23 (= ATCC 700759) are additional strains of Legionella gresilensis.

\section{ACKNOWLEDGEMENTS}

We are grateful to Hans G. Trüper (University of Bonn, Bonn, Germany) for his help in the latinization of the new species names. We also thank Patricia Luis and Elisabeth Nunes for their technical help. We are also grateful to all the staff of the 'Archives municipales de Montbéliard' (Montbéliard, Franche-Comté, France) for their helpful knowledge.

\section{REFERENCES}

Adeleke, A., Pruckler, J., Benson, R. F., Rowbotham, T., Halablab, M. \& Fields, B. (1996). Legionella-like amebal pathogens phylogenetic status and possible role in respiratory disease. Emerg Infect Dis 2, 225-230.

Adeleke, A., Fields, B. S., Benson, R. F. \& 8 other authors (2001). Legionella drozanskii sp. nov., Legionella rowbothamii sp. nov. and Legionella fallonii sp. nov.: three unusual new Legionella species. Int J Syst Evol Microbiol 51, 1151-1160.

Altschul, S. F., Madden, T. L., Schaffer, A. A., Zhang, J., Zhang, Z., Miller, W. \& Lipman, D. J. (1997). Gapped BLAST and PSI-BLAST: a new generation of protein database search programs. Nucleic Acids Res 25, 3389-3402.

Benson, R. F., Thacker, W. L., Daneshvar, M. I. \& Brenner, D. J. (1996). Legionella waltersii sp. nov. and an unnamed Legionella genomospecies isolated from water in Australia. Int $J$ Syst Bacteriol 46, 631-634.

Birtles, R. J., Rowbotham, T. J., Raoult, D. \& Harrison, T. G. (1996). Phylogenetic diversity of intra-amoebal legionellae as revealed by $16 \mathrm{~S}$ rRNA gene sequence comparison. Microbiology $\mathbf{1 4 2}$, 3525-3530.

Bornstein, N., Marmet, D., Surgot, M. \& 9 other authors (1989). Legionella gratiana sp. nov. isolated from French spa water. Res Microbiol 140, 541-552.

Brenner, D. J., Steigerwalt, A. G. \& McDade, J. E. (1979). Classification of the Legionnaires' disease bacterium: Legionella pneumophila, genus novum, species nova, of the family Legionellaceae, familia nova. Ann Intern Med 90, 656-658.

Brenner, D. J., McWhorter, A. C., Knutson, J. K. \& Steigerwalt, A. G. (1982). Escherichia vulneris: a new species of Enterobacteriaceae associated with human wounds. J Clin Microbiol 15, 1133-1140.

Brenner, D. J., Steigerwalt, A. G., Gorman, G. W. \& 13 other authors (1985). Ten new species of Legionella. Int $J$ Syst Bacteriol 35, 50-59.

Brenner, D. J., Steigerwalt, A. G., Epple, P. \& 7 other authors (1988). Legionella pneumophila serogroup Lansing 3 isolated from a patient with fatal pneumonia and descriptions of $L$. pneumophila subsp. pneumophila subsp. nov., L. pneumophila subsp. fraseri subsp. nov., and L. pneumophila subsp. pascullei subsp. nov. J Clin Microbiol 26, 1695-1703.

Brosius, J., Palmer, M. L., Kennedy, P. J. \& Noller, H. F. (1978). Complete nucleotide sequence of a $16 \mathrm{~S}$ ribosomal RNA gene from Escherichia coli. Proc Natl Acad Sci U S A 75, 4801-4805. 
Cherry, W. B., Pittman, B., Harris, P. P., Hebert, G. A., Thomason, B. M., Thacker, L. \& Weaver, R. E. (1978). Detection of Legionnaires disease bacteria by direct immunofluorescent staining. $J$ Clin Microbiol 8, 329-338.

Crosa, J. H., Brenner, D. J. \& Falkow, S. (1973). Use of singlestrand specific nuclease for analysis of bacterial and plasmid deoxyribonucleic acid homo- and heteroduplexes. $J$ Bacteriol 115, 904-911.

Dice, L. R. (1945). Measures of the amount of ecological association between species. Ecology 26, 297-302.

Fabbi, M., Pastoris, M. C., Scanziani, E., Magnino, S. \& Di Matteo, L. (1998). Epidemiological and environmental investigations of Legionella pneumophila infection in cattle and case report of fatal pneumonia in a calf. J Clin Microbiol 36, 1942-1947.

Fliermans, C. B. (1996). Ecology of Legionella: from data to knowledge with a little wisdom. Microb Ecol 32, 203-228.

Fliermans, C. B., Cherry, W. B., Orrison, L. H., Smith, S. J., Tison, D. L. \& Pope, D. H. (1981). Ecological distribution of Legionella pneumophila. Appl Environ Microbiol 41, 9-16.

Franzin, L. \& Gioannini, P. (2000). Legionella taurinensis, a new species of Legionella isolated in Turin, Italy. Int J Syst Evol Microbiol 50, 937.

Fry, N. K., Warwick, S., Saunders, N. A. \& Embley, T. M. (1991). The use of $16 \mathrm{~S}$ ribosomal RNA analyses to investigate the phylogeny of the family Legionellaceae. J Gen Microbiol 137, 1215-1222.

Gomez-Lus, P., Fields, B. S., Benson, R. F., Martin, W. T., O'Connor, S. P. \& Black, C. M. (1993). Comparison of arbitrarily primed polymerase chain reaction, ribotyping, and monoclonal antibody analysis for subtyping Legionella pneumophila serogroup 1. J Clin Microbiol 31, 1940-1942.

Grimont, P. A. D., Popoff, M. Y., Grimont, F., Coynault, C. \& Lemelin, M. (1980). Reproducibility and correlation study of three deoxyribonucleic-acid hybridization procedures. Curr Microbiol 4, 325-330.

Grimont, F., Lefèvre, M., Ageron, E. \& Grimont, P. A. D. (1989). rRNA gene restriction patterns of Legionella species: a molecular identification system. Res Microbiol 140, 615-626.

Hookey, J. V., Saunders, N. A., Fry, N. K., Birtles, R. J. \& Harrison, T. G. (1996). Phylogeny of Legionellaceae based on smallsubunit ribosomal DNA sequences and proposal of Legionella lytica comb. nov. for Legionella-like amoebal pathogens. Int $J$ Syst Bacteriol 46, 526-531.

Kaneko, T., Katoh, K., Fujimoto, M., Kumagai, M., Tamoka, J. \& Katayama-Fujimura, Y. (1986). Determination of the nucleotide composition of a deoxyribonucleic acid by high-performance liquid chromatography of its enzymatic hydrolysate: a review. J Microbiol Methods 4, 229-240.

Lambert, M. A. \& Moss, C. W. (1989). Cellular fatty acid compositions and isoprenoid quinone contents of 23 Legionella species. J Clin Microbiol 27, 465-473.

Lo Presti, F., Riffard, S., Vandenesch, F., Reyrolle, M., Ronco, E., Ichai, P. \& Etienne, J. (1997). The first clinical isolate of Legionella parisiensis, from a liver transplant patient with pneumonia. $J$ Clin Microbiol 35, 1706-1709.

Lo Presti, F., Riffard, S., Vandenesch, F. \& Etienne, J. (1998). Identification of Legionella species by random amplified polymorphic DNA profiles. J Clin Microbiol 36, 3193-3197.
Lo Presti, F., Riffard, S., Meugnier, H. \& 8 other authors (1999). Legionella taurinensis sp. nov., a new species antigenically similar to Legionella spiritensis. Int J Syst Bacteriol 49, 397-403.

Marmur, J. \& Doty, P. (1962). Determination of the base composition of deoxyribonucleic acid from its thermal denaturation temperature. J Mol Biol 5, 109-118.

Meunier, J.-R. \& Grimont, P.A. D. (1993). Factors affecting reproducibility of random amplified polymorphic DNA fingerprinting. Res Microbiol 144, 373-379.

Murdoch, D. R., Light, G. J., Jennings, L. C. \& Chambers, S. T. (1999). Sequence-based classification scheme for the genus Legionella targeting the 5S rRNA gene. J Clin Microbiol 37, 281.

Newsome, A. L., Scott, T. M., Benson, R. F. \& Fields, B. S. (1998). Isolation of an amoeba naturally harboring a distinctive Legionella species. Appl Environ Microbiol 64, 1688-1693.

Ratcliff, R. M., Lanser, J. A., Manning, P. A. \& Heuzenroeder, M. W. (1998). Sequence-based classification scheme for the genus Legionella targeting the mip gene. J Clin Microbiol 36, 1560-1567.

Riffard, S., Lo Presti, F., Normand, P., Forey, F., Reyrolle, M., Etienne, J. \& Vandenesch, F. (1998). Species identification of Legionella via intergenic $16 \mathrm{~S}-23 \mathrm{~S}$ ribosomal spacer PCR analysis. Int J Syst Bacteriol 48, 723-730.

Sanger, F., Nicklen, S. \& Coulson, A. R. (1977). DNA sequencing with chain-terminating inhibitors. Proc Natl Acad Sci U S A 74, 5463-5467.

Stackebrandt, E. \& Goebel, B. M. (1994). Taxonomic note: a place for DNA-DNA reassociation and 16S rRNA sequence analysis in the present species definition in bacteriology. Int $J$ Syst Bacteriol 44, 846-849.

Stout, J. E., Yu, V. L. \& Best, M. G. (1985). Ecology of Legionella pneumophila within water distribution systems. Appl Environ Microbiol 49, 221-228.

Thacker, W. L., Plikaytis, B. B. \& Wilkinson, H. W. (1985). Identification of 22 Legionella species and 33 serogroups with the slide agglutination test. J Clin Microbiol 21, 779-782.

Ursing, J. B., Rosselló-Mora, R. A., García-Valdés, E. \& Lalucat, J. (1995). Taxonomic note: a pragmatic approach to the nomenclature of phenotypically similar genomic groups. Int J Syst Bacteriol 45, 604

Vickers, R. M. \& Yu, V. L. (1984). Clinical laboratory differentiation of Legionellaceae family members with pigment production and fluorescence on media supplemented with aromatic substrates. J Clin Microbiol 19, 583-587.

Vickers, R. M., Stout, J. E., Yu, V. L. \& Rihs, J. D. (1987). Manual of culture methodology for Legionella. Semin Respir Infect $\mathbf{2}$, 274-279.

Wayne, L. G., Brenner, D. J., Colwell, R. R. \& 9 other authors (1987). International Committee on Systematic Bacteriology. Report of the ad hoc committee on reconciliation of approaches to bacterial systematics. Int J Syst Bacteriol 37, 463-464.

Wilkinson, I. J., Sangster, N., Ratcliff, R. M., Mugg, P. A., Davos, D. E. \& Lanser, J. A. (1990). Problems associated with identification of Legionella species from the environment and isolation of six possible new species. Appl Environ Microbiol 56, 796-802. 